\title{
Editorial
}

\section{Should We Screen for Pulmonary Hypertension at the Initial Evaluation of Idiopathic Pulmonary Fibrosis?}

\author{
Laurent Savale $^{\mathrm{a}}$ Laurent Bertoletti $^{\mathrm{b}} \quad$ Vincent Cottin $^{\mathrm{c}}$ \\ ${ }^{a}$ Reference Centre for Severe Pulmonary Hypertension, Department of Respiratory Medicine, AP-HP, Hôpital Bicêtre, \\ INSERM U999, University Paris Sud, Le Kremlin-Bicêtre, ${ }^{b}$ Department of Therapeutic Medicine, CHU Saint-Etienne, \\ University of Saint-Etienne, Thrombosis Research Group, EA3065, Saint-Etienne, and 'Hospices Civils de Lyon, \\ Reference Center for Rare Pulmonary Diseases, Department of Respiratory Medicine, Louis Pradel Hospital, UMR 754 \\ INRA-Vetagrosup EPHE IFR 128, University Claude Bernard Lyon 1, Lyon, France
}

Idiopathic pulmonary fibrosis (IPF) is a chronic progressive disease that leads to respiratory failure and death with a median survival of 2.5-3 years from the time of diagnosis [1]. Progress has been made recently in the diagnosis [2] and evaluation of prognosis [3, 4]. An accurate evaluation of the risk of death is essential to inform patients and help transplant decisions in subjects less than 60-65 years old who have limited comorbidities. Although pirfenidone and nintedanib have recently been shown to reduce the rate of decline in lung function in patients with mild-to-moderate IPF $[5,6]$, the management of advanced disease remains mostly supportive especially when lung transplant is contraindicated.

Pulmonary hypertension $(\mathrm{PH})$ is relatively frequent in patients with advanced chronic respiratory disorders including IPF [7] and other chronic lung diseases including chronic obstructive pulmonary disease [8]. Because all these conditions create hypoxia, they are considered as separate entities according to the etiologic classification of PH (group 3) [9]. When present in the setting of IPF, $\mathrm{PH}$ is associated with increased dyspnea, decreased exercise capacity, greater oxygen requirements, lower diffus- ing capacity of the lung for carbon monoxide (DLCO) and reduced survival $[7,10]$. However, the prevalence of $\mathrm{PH}$ in IPF varies depending upon the procedures, diagnostic algorithm, definition used, and the severity of the underlying parenchymal impairment. Hemodynamic data are mainly available in the setting of patients with severe disease, who are referred for lung transplant and routinely undergo right-heart catheterization (RHC) - a mandatory procedure to diagnose precapillary $\mathrm{PH}$. Precapillary $\mathrm{PH}$ (defined by a mean pulmonary artery pressure (mPAP) of $25 \mathrm{~mm} \mathrm{Hg}$ or greater and a pulmonary artery wedge pressure of $15 \mathrm{~mm} \mathrm{Hg}$ or less) is present in $32-46 \%$ of IPF patients evaluated or listed for lung transplant [1013]. In addition, severe $\mathrm{PH}$ ( $\mathrm{mPAP} \geq 40 \mathrm{~mm} \mathrm{Hg}$ ) is present in $2-10 \%$ of patients $[10,11]$.

In contrast, because no specific therapy for $\mathrm{PH}$ is recommended in chronic respiratory diseases, and because the practical consequences of detecting $\mathrm{PH}$ at an early stage are unclear, very few studies have focused on $\mathrm{PH}$ in IPF patients with moderate functional impairment. In a series of 61 patients with IPF [14] who underwent RHC at initial evaluation, a value of $\mathrm{mPAP}$ greater than $17 \mathrm{~mm}$

\section{KARGER}

E-Mail karger@karger.com www.karger.com/res
(C) 2013 S. Karger AG, Basel

0025-7931/13/0856-0452\$38.00/0
Vincent Cottin

Hôpital Louis Pradel

FR-69677 Lyon Cedex (France)

E-Mail vincent.cottin@chu-lyon.fr 
$\mathrm{Hg}$ was associated with a higher relative risk of mortality within 5 years. Patients had mild-to-moderate IPF, with a mean value of forced vital capacity (FVC) of $76 \%$ of predicted and a mean DLCO of $45 \%$ of predicted. Interestingly, FVC did not differ between patients with an $\mathrm{mPAP}$ lower or greater than $17 \mathrm{~mm} \mathrm{Hg}$, suggesting that the development of $\mathrm{PH}$ may be related to remodeling of the pulmonary arteries independent of the severity of lung fibrosis or hypoxemia.

In the present issue of Respiration, Kimura et al. [15] report on the prevalence of $\mathrm{PH}$ as assessed by $\mathrm{RHC}$ at the initial evaluation of 101 patients with mild-to-moderate functional impairment (mean FVC: $70 \%$ of predicted; mean DLCO: $48 \%$ of predicted; mean 6-min walk distance: $527 \mathrm{~m}$; mean $\mathrm{PaO}_{2}$ at room air: $79 \mathrm{~mm} \mathrm{Hg}$ ). $\mathrm{PH}$ defined as mPAP greater than $25 \mathrm{~mm} \mathrm{Hg}$ was present in $14.9 \%$ of patients (and $>35 \mathrm{~mm} \mathrm{Hg}$ in 5\%), highlighting that $\mathrm{PH}$ can develop in IPF patients without chronic hypoxia and/ or severe capillary destruction. It is likely that the pathophysiology of pulmonary vascular remodeling in patients with IPF is complex and multifactorial and not limited to vascular destruction in fibrotic areas [16-18], involving local and systemic inflammatory processes, environmental factors including tobacco smoking and probably still unknown genetic predisposition.

Furthermore, $19.8 \%$ of patients in this series had borderline values of mPAP (e.g. between 21 and $25 \mathrm{~mm} \mathrm{Hg}$ ) [15]. Further, receiver operating curve analysis demonstrated that a cutoff of $20 \mathrm{~mm} \mathrm{Hg}$ for mPAP best predicted survival, with a median survival of 20.8 months in patients with mPAP greater than $20 \mathrm{~mm} \mathrm{Hg}$ compared to 37.5 months in those with mPAP not greater than $20 \mathrm{~mm}$ $\mathrm{Hg}(\mathrm{p}=0.001)$. In contrast to previous work [14], the prognostic value of this cutoff was confirmed using multivariate analysis, with FVC being another independent predictor of prognosis (as demonstrated in numerous previous studies). Furthermore, mPAP greater than 20 $\mathrm{mm} \mathrm{Hg}$ was associated with lower DLCO, lower $\mathrm{PaO}_{2}$ and a 100-meter reduction in 6-min walk distance. This does not demonstrate that a threshold of $20 \mathrm{~mm} \mathrm{Hg}$ should be used to define PH in IPF; however, the area under the curve was rather low (0.679) and a prospective evaluation in independent studies is definitely required. There is accumulating evidence that borderline mean pulmonary pressures may be clinically relevant in patients with systemic sclerosis; the study by Kimura et al. [15] indicates that the relevance of mildly elevated pulmonary pressures also warrants further scrutiny in the context of IPF.

Unfortunately, this study suffers from a number of limitations [19], including its retrospective design with a large number of missing data (101 out of 172 patients could be evaluated) [15] and possible selection and evaluation bias. Pulmonary artery wedge pressure was significantly more elevated in patients with MPAP greater than $20 \mathrm{~mm} \mathrm{Hg}$, suggesting that coexisting left heart disease (a frequent finding in the context of IPF) may have contributed to $\mathrm{PH}$. Further, the lack of a review of chest imaging precluded the appropriate evaluation of the proportion of patients who may have had significant emphysema at computed tomography of the chest, as suggested by the imbalance in the proportion of smokers and the preservation of lung volumes together with decreased DLCO in some patients. Indeed, the syndrome of combined pulmonary fibrosis and emphysema is associated with a high risk of $\mathrm{PH}$ carrying a dismal prognosis [20-22], and must be taken into account whenever assessing $\mathrm{PH}$ in the setting of IPF.

Beyond the important findings that $\mathrm{PH}$ is frequent and clinically relevant in IPF, the study by Kimura et al. [15] raises the question of systematic screening for $\mathrm{PH}$ at the initial evaluation of IPF. As RHC cannot be performed routinely in all patients diagnosed with IPF and during follow-up, an appropriate method remains to be found to screen for PH. Indications for RHC in the setting of IPF have been proposed [7] and remain to be evaluated. Currently, RHC may be reserved for patients who exhibit signs and symptoms of right-heart dysfunction, including clinical worsening disproportionate to ventilatory impairment (especially in the context of DLCO lower than $40 \%$ predicted and/or combined emphysema). RHC may also be warranted in patients being evaluated for lung transplantation, when an accurate prognostic assessment is critical, when off-label treatment is considered due to severe $\mathrm{PH}$ at echocardiography, and in selected cases with suspected diastolic dysfunction. Transthoracic echocardiography is generally performed prior to RHC although the measurement of tricuspid regurgitation velocity might be difficult and imprecise [23]. Beside the prognostic impact, would the early diagnosis of $\mathrm{PH}$ influence the management of patients recently diagnosed with IPF, e.g. would it lead to changes in therapy that may improve their functional status or survival? If $\mathrm{PH}$ contributes to poor prognosis in IPF even with mild restrictive physiology, it would be reasonable to expect that therapies targeting vascular remodeling would offer a viable approach. $\mathrm{PH}$-specific therapy in this indication, however, has not demonstrated a clear benefit in prospective studies using phosphodiesterase-4 inhibitors [24-26], endothelin-1 receptor antagonists [27], and the recently developed stimulator of soluble guanylate cyclase riociguat [28]. It is also impor- 
tant to emphasize that vasodilators used in the treatment of $\mathrm{PH}$ can have deleterious effects on gas exchange. In addition, the endothelin receptor antagonist ambrisentan has proven deleterious in patients with IPF [27] and must be avoided in this setting. Further trials are necessary in $\mathrm{PH}$ associated with IPF, and it may prove necessary in the future to better characterize the subgroup of patients who could benefit from $\mathrm{PH}$-specific therapies, presumably among subjects with disproportionate elevation of pulmonary vascular resistance as compared to the severity of pulmonary fibrosis and restrictive physiology.

Notwithstanding the limitations, this observational study sheds new light on the prognostic impact of early pulmonary vascular remodeling in patients with IPF. PH is an essential part of the assessment of disease severity, and a mild elevation of mPAP (borderline $\mathrm{PH}$ ) may be associated with a shorter survival. Prospective studies are needed to determine the best methods to screen for $\mathrm{PH}$ in
IPF, and the potential efficacy of $\mathrm{PH}$ therapy to improve the functional status and prognosis of patients must be carefully evaluated by randomized, controlled studies. Both conditions are necessary before the routine screening for PH may be considered in all patients with IPF.

\section{Financial Disclosure and Conflicts of Interest}

Dr. L. Savale has relationships with the drug companies Actelion, Bayer, GSK and Pfizer. In addition, he has been an investigator in trials of these companies; his relationships have also included consultancy services.

Dr. L. Bertoletti has received fees for speaking from Actelion, GSK and Pfizer (in the field of pulmonary hypertension).

Dr. V. Cottin has received fees for speaking from Actelion, Bayer, Boehringer Ingelheim, GSK, Intermune, Lilly, Novartis and Pfizer; he has been an investigator in clinical trials of these companies and has served on their advisory boards.

\section{References}

1 Raghu G, Collard HR, Egan JJ, Martinez FJ, Behr J, Brown KK, Colby TV, Cordier JF, Flaherty KR, Lasky JA, Lynch DA, Ryu JH, Swigris JJ, Wells AU, Ancochea J, Bouros D, Carvalho C, Costabel U, Ebina M, Hansell DM, Johkoh T, Kim DS, King TE Jr, Kondoh Y, Myers J, Muller NL, Nicholson AG, Richeldi L, Selman M, Dudden RF, Griss BS, Protzko SL, Schunemann HJ: An official ATS/ERS/ JRS/ALAT statement: idiopathic pulmonary fibrosis: evidence-based guidelines for diagnosis and management. Am J Respir Crit Care Med 2011;183:788-824.

-2 du Bois RM: An earlier and more confident diagnosis of idiopathic pulmonary fibrosis. Eur Respir Rev 2012;21:141-146.

$\checkmark 3$ Ley B, Collard HR, King TE Jr: Clinical course and prediction of survival in idiopathic pulmonary fibrosis. Am J Respir Crit Care Med 2011;183:431-440.

-4 Ley B, Ryerson CJ, Vittinghoff E, Ryu JH, Tomassetti S, Lee JS, Poletti V, Buccioli M, Elicker BM, Jones KD, King TE Jr, Collard HR: A multidimensional index and staging system for idiopathic pulmonary fibrosis. Ann Intern Med 2012;156:684-691.

-5 Noble PW, Albera C, Bradford WZ, Costabel U, Glassberg MK, Kardatzke D, King TE Jr, Lancaster L, Sahn SA, Szwarcberg J, Valeyre D, du Bois RM: Pirfenidone in patients with idiopathic pulmonary fibrosis (capacity): two randomised trials. Lancet 2011;377:17601769.
6 Richeldi L, Costabel U, Selman M, Kim DS, Hansell DM, Nicholson AG, Brown KK, Flaherty KR, Noble PW, Raghu G, Brun M, Gupta A, Juhel N, Kluglich M, du Bois RM: Efficacy of a tyrosine kinase inhibitor in idiopathic pulmonary fibrosis. N Engl J Med 2011;365: 1079-1087.

7 Nathan SD, Cottin V: Pulmonary hypertension in patients with idiopathic pulmonary fibrosis. Eur Respir Mon 2012;57:148-160.

8 Chaouat A, Minai OA: Pulmonary hypertension in patients with COPD. Eur Respir Mon 2012;57:138-147.

-9 Galie N, Hoeper MM, Humbert M, Torbicki A, Vachiery JL, Barbera JA, Beghetti M, Corris P, Gaine S, Gibbs JS, Gomez-Sanchez MA, Jondeau G, Klepetko W, Opitz C, Peacock A, Rubin L, Zellweger M, Simonneau G: Guidelines for the diagnosis and treatment of pulmonary hypertension. The task force for the diagnosis and treatment of pulmonary hypertension of the European Society of Cardiology (ESC) and the European Respiratory Society (ERS), endorsed by the International Society of Heart and Lung Transplantation (ISHLT). Eur Respir J 2009;34:1219-1263.

10 Lettieri CJ, Nathan SD, Barnett SD, Ahmad S, Shorr AF: Prevalence and outcomes of pulmonary arterial hypertension in advanced idiopathic pulmonary fibrosis. Chest 2006;129: 746-752.

11 Shorr AF, Wainright JL, Cors CS, Lettieri CJ, Nathan SD: Pulmonary hypertension in patients with pulmonary fibrosis awaiting lung transplant. Eur Respir J 2007;30:715-721.
12 Zisman DA, Ross DJ, Belperio JA, Saggar R, Lynch JP 3rd, Ardehali A, Karlamangla AS: Prediction of pulmonary hypertension in idiopathic pulmonary fibrosis. Respir Med 2007;101:2153-2159.

13 Nathan SD, Shlobin OA, Barnett SD, Saggar R, Belperio JA, Ross DJ, Ahmad S, Saggar R, Libre E, Lynch JP 3rd, Zisman DA: Right ventricular systolic pressure by echocardiography as a predictor of pulmonary hypertension in idiopathic pulmonary fibrosis. Respir Med 2008;102:1305-1310.

14 Hamada K, Nagai S, Tanaka S, Handa T, Shigematsu M, Nagao T, Mishima M, Kitaichi M, Izumi T: Significance of pulmonary arterial pressure and diffusion capacity of the lung as prognosticator in patients with idiopathic pulmonary fibrosis. Chest 2007;131:650-656.

15 Kimura M, Taniguchi H, Kondoh Y, Kimura T, Kataoka K, Nishiyama O, Aso H, Sakamoto K, Hasegawa Y: Pulmonary hypertension as a prognostic indicator at the initial evaluation in idiopathic pulmonary fibrosis. Respiration 2013;85:456-463.

16 Farkas L, Gauldie J, Voelkel NF, Kolb M: Pulmonary hypertension and idiopathic pulmonary fibrosis: a tale of angiogenesis, apoptosis, and growth factors. Am J Respir Cell Mol Biol 2011;45:1-15.

17 Ventetuolo CE, Kawut SM, Lederer DJ: Plasma endothelin-1 and vascular endothelial growth factor levels and their relationship to hemodynamics in idiopathic pulmonary fibrosis. Respiration 2012;84:299-305. 
18 Pitsiou G, Papakosta D, Bouros D: Pulmonary hypertension in idiopathic pulmonary fibrosis: a review. Respiration 2011;82:294-304.

19 Aggarwal D, Aggarwal P: Pulmonary hypertension as a prognostic factor in idiopathic pulmonary fibrosis. Respiration2013;85:521.

-20 Cottin V, Nunes H, Brillet PY, Delaval P, Devouassoux $\mathrm{G}$, Tillie-Leblond I, Israel-Biet $\mathrm{D}$, Court-Fortune I, Valeyre D, Cordier JF: Combined pulmonary fibrosis and emphysema: a distinct underrecognised entity. Eur Respir J 2005;26:586-593.

21 Cottin V, Le Pavec J, Prevot G, Mal H, Humbert M, Simonneau G, Cordier JF: Pulmonary hypertension in patients with combined pulmonary fibrosis and emphysema syndrome. Eur Respir J 2010;35:105-111.
22 Mejia M, Carrillo G, Rojas-Serrano J, Estrada A, Suarez T, Alonso D, Barrientos E, Gaxiola M, Navarro C, Selman M: Idiopathic pulmonary fibrosis and emphysema: decreased survival associated with severe pulmonary arterial hypertension. Chest 2009;136:10-15.

23 Arcasoy SM, Christie JD, Ferrari VA, Sutton MS, Zisman DA, Blumenthal NP, Pochettino A, Kotloff RM: Echocardiographic assessment of pulmonary hypertension in patients with advanced lung disease. Am J Respir Crit Care Med 2003;167:735-740.

24 Collard HR, Anstrom KJ, Schwarz MI, Zisman DA: Sildenafil improves walk distance in idiopathic pulmonary fibrosis. Chest 2007; 131:897-899.

25 Zisman DA, Schwarz M, Anstrom KJ, Collard HR, Flaherty KR, Hunninghake GW: A controlled trial of sildenafil in advanced idiopathic pulmonary fibrosis. N Engl J Med 2010;363: 620-628.
26 Jackson RM, Glassberg MK, Ramos CF, Bejarano PA, Butrous G, Gomez-Marin O: Sildenafil therapy and exercise tolerance in idiopathic pulmonary fibrosis. Lung 2010;188: 115-123.

27 Raghu G, Behr J, Brown KK, Egan J, Kawut SM, Flaherty KR, Martinez FJ, Nathan SD, Wells AU, Pedersen P, Shao L, Chien J, O'Riordan T: ARTEMIS-IPF: a placebo-controlled trial of ambrisentan in idiopathic pulmonary fibrosis. Am J Respir Crit Care Med 2012;185:A3632.

28 Hoeper MM, Halank M, Wilkens H, Günther A, Weimann G, Gebert I, Leuchte H, Behr J: Riociguat for interstitial lung disease and pulmonary hypertension: a pilot trial. Eur Respir $\mathrm{J}$, in press. 